\title{
Radiolabeled Antibodies Against Müllerian-Inhibiting Substance Receptor, Type II: New Tools for a Theranostic Approach in Ovarian Cancer
}

\author{
Emmanuel Deshayes*1,2, Riad Ladjohounlou*1, Pierre Le Fur ${ }^{1}$, Alexandre Pichard ${ }^{1}$, Catherine Lozza ${ }^{1}$, \\ Vincent Boudousq ${ }^{1}$, Samuel Sevestre ${ }^{1}$, Marta Jarlier ${ }^{2}$, Roxana Kashani ${ }^{3}$, Joanna Koch ${ }^{3}$, Jane Sosabowski ${ }^{3}$, Julie Foster ${ }^{3}$, \\ Nicolas Chouin ${ }^{4,5}$, Frank Bruchertseifer ${ }^{6}$, Alfred Morgenstern ${ }^{6}$, Pierre-Olivier Kotzki ${ }^{1,2}$, Isabelle Navarro-Teulon ${ }^{\dagger 1}$, \\ and Jean-Pierre Pouget ${ }^{\dagger 1}$ \\ ${ }^{I}$ Institut de Recherche en Cancérologie de Montpellier (IRCM), INSERM, Université de Montpellier, Institut Régional du Cancer de \\ Montpellier (ICM), Montpellier, France; ${ }^{2}$ Institut régional du Cancer de Montpellier, Montpellier, France; ${ }^{3}$ Centre for Molecular \\ Oncology, Barts Cancer Institute, Queen Mary University of London, London, United Kingdom; ${ }^{4}$ Nantes-Angers Cancer Research \\ Center CRCINA, University of Nantes, INSERM UMR1232, CNRS-ERL6001, Nantes, France; ${ }^{5}$ Oniris, AMaROC Unit, Nantes, \\ France; and ${ }^{6}$ Directorate for Nuclear Safety and Security, Joint Research Centre, European Commission, Karlsruhe, Germany
}

We have developed the 16F12 mouse monoclonal antibody (mAb), which targets the Müllerian-inhibiting substance receptor, type ॥ (MISRII), expressed by ovarian tumors. Here, we assessed in preclinical models the possibility of using radiolabeled $16 \mathrm{~F} 12$ in a theranostic approach for small-volume ovarian peritoneal carcinomatosis, such as after cytoreductive surgery. Methods: DOTA-, DTPA- or deferoxamine mesylate-conjugated $16 \mathrm{~F} 12 \mathrm{mAb}$ was radiolabeled with $\beta$-particle ( $\left.{ }^{177} \mathrm{Lu}\right)$ or a-particle (213Bi) emitters for therapeutic use and with ${ }^{89} \mathrm{Zr}$ for PET imaging. On the 13 th postxenograft day, mice bearing intraperitoneal MISRII-positive AN3CA endometrial carcinoma cell xenografts were treated by conventional intraperitoneal radioimmunotherapy (IP-RIT) with $10 \mathrm{MBq}$ of ${ }^{177} \mathrm{Lu}-$ $16 \mathrm{~F} 12$ or $12.9 \mathrm{MBq}$ of ${ }^{213} \mathrm{Bi}-16 \mathrm{~F} 12$ or by brief intraperitoneal radioimmunotherapy (BIP-RIT) using $50 \mathrm{MBq}$ of ${ }^{177} \mathrm{Lu}-16 \mathrm{~F} 12$ or $37 \mathrm{MBq}$ of ${ }^{213} \mathrm{Bi}-16 \mathrm{~F} 12$. For BIP-RIT, 30 min after injection of the radiolabeled mAbs, the peritoneal cavity was washed to remove the unbound radioactivity. The biodistribution of ${ }^{177} \mathrm{Lu}$ - and ${ }^{213} \mathrm{Bi}-16 \mathrm{~F} 12 \mathrm{mAbs}$ was determined and then used for dose assessment. Hematologic toxicity was also monitored. Results: The $16 \mathrm{~F} 12$ mAb was satisfactorily radiolabeled for both therapy and imaging. IP-RIT with ${ }^{177} \mathrm{Lu}-$ $16 \mathrm{~F} 12$ was slightly more efficient in delaying tumor growth than IP-RIT with ${ }^{213} \mathrm{Bi}-16 \mathrm{~F} 12$. Conversely, ${ }^{213} \mathrm{Bi}-16 \mathrm{~F} 12$ was more efficient than ${ }^{177} \mathrm{Lu}-16 \mathrm{~F} 12$ in BIP-RIT. The biodistribution analysis showed that the tumor-to-blood uptake ratio was significantly higher with BIP-RIT than with IP-RIT for both ${ }^{213} \mathrm{Bi}-$ and ${ }^{177} \mathrm{Lu}-16 \mathrm{~F} 12$. Hematologic toxicity was more pronounced with ${ }^{177} \mathrm{Lu}-16 \mathrm{~F} 12$ than with ${ }^{213} \mathrm{Bi}-16 \mathrm{~F} 12$. SPECT/CT images (after BIP-RIT with ${ }^{177} \mathrm{Lu}-16 \mathrm{~F} 12$ ) and PET/CT images (after injection of ${ }^{89} \mathrm{Zr}-16 \mathrm{~F} 12$ in the tail vein) showed focal uptake at the tumor site. Conclusion: Radiolabeled 16F12 could represent a new theranostic tool for small-volume ovarian peritoneal carcinomatosis. Specifically, ${ }^{213} \mathrm{Bi}-16 \mathrm{~F} 12-$ based BIP-RIT could be proposed to selected patients as an alternative adjuvant treatment imme-

Received Jan. 20, 2018; revision accepted Feb. 27, 2018

For correspondence or reprints contact: Jean-Pierre Pouget, INSERM U1194, Institut de Recherche en Cancérologie, 34298 Montpellier Cedex 5, France.

E-mail: jean-pierre.pouget@inserm.fr

${ }^{*}$ Contributed equally to this work.

tContributed equally to this work

Published online Apr. 19, 2018.

COPYRIGHT (c) 2018 by the Society of Nuclear Medicine and Molecular Imaging. diately after cytoreductive surgery. An anti-MISRII mAb is currently being used in a first-in-human study, thus making radiolabeled antiMISRII mAbs a realistic theranostic option for the clinic.

Key Words: targeted radiotherapy; radioimmunotherapy; theranostic; MISRII; ${ }^{213} \mathrm{Bi}$; ${ }^{177} \mathrm{Lu}$; ovarian; peritoneal carcinomatosis

J Nucl Med 2018; 59:1234-1242

DOI: 10.2967/jnumed.118.208611

$\mathbf{O}$ varian cancer is the most lethal gynecologic malignancy (1). Most ovarian cancers (90\%) are of epithelial origin, and sex cord/ stromal (including granulosa cell tumors) and germ cell tumors account for the remaining $10 \%$. Optimal treatment is usually based on cytoreductive surgery to remove the macroscopic disease and on systemic chemotherapy with paclitaxel and carboplatin. However, the 5-y overall survival rate remains poor (46\%) (2), partly because ovarian cancer progresses without detectable symptoms or clinical signs in most patients, leading to late-stage diagnosis $(>70 \%$ at stage III or IV) when the disease has spread to the peritoneal cavity as peritoneal carcinomatosis. Treatment of peritoneal carcinomatosis relies on cytoreductive surgery to remove the macroscopic disease, followed by intraperitoneal adjuvant platinum-based chemotherapy, which significantly increases overall and progression-free survival compared with intravenous chemotherapy (3). Although many women respond well to this therapeutic approach, disease recurs in $70 \%-90 \%$ of responders but remains localized in the peritoneal cavity. In the 1980s, Sugarbaker proposed the combination of cytoreductive surgery and hyperthermic intraperitoneal chemotherapy to treat the residual disease in selected patients with peritoneal carcinomatosis (4). Hyperthermic intraperitoneal chemotherapy increases survival in patients with primary recurrent disease and is today used as first- or second-line therapy (5). However, because morbidity has been one of the main drawbacks of hyperthermic intraperitoneal chemotherapy, it is not recommended outside clinical trials (6).

Many studies have investigated the efficacy of radioimmunotherapy as an option for peritoneal carcinomatosis using $\beta$-particle 
(7-17), $\alpha$-particle (18-23) (24), or Auger-particle (25-27) emitters in preclinical and clinical models (28). Particularly, radioimmunotherapy at the surgery block could represent an advantage over current treatments. In 2010, we proposed brief intraperitoneal radioimmunotherapy (BIP-RIT) (25) for the treatment of colorectal cancer peritoneal carcinomatosis in mice. BIP-RIT includes intraperitoneal injection of high activities of radiolabeled monoclonal antibodies (mAbs) that are left in the peritoneal cavity for less than $1 \mathrm{~h}$, as is the case for hyperthermic intraperitoneal chemotherapy. Then, the peritoneal cavity is extensively washed with saline solution using a peristaltic pump to remove the unbound radioactivity (Fig. 1).

To specifically target ovarian cancer, we developed the $16 \mathrm{~F} 12$ murine $\mathrm{mAb}$ against the human Müllerian-inhibiting substance receptor, type II (MISRII; also known as anti-Müllerian hormone receptor, type II). The ligand for MISRII is anti-Müllerian hormone, a $140-\mathrm{kDa}$ dimeric glycoprotein, also called Müllerianinhibiting substance. This is a member of the transforming growth factor- $\beta$ family that regulates tissue growth and differentiation (29). Human MISRII is a 66-kDa glycosylated single-transmembrane domain receptor that includes a 17 -amino-acid signal peptide, a 127-amino-acid extracellular region, a 26-amino-acid transmembrane domain, and an intracellular region of 403 amino acids bearing the serine/threonine kinase activity (30,31). MISRII is detected in $100 \%$ of granulosa cell tumors (32), in almost $70 \%$ of epithelial ovarian cancers, in $77 \%$ of ovarian dysgerminomas, and in $75 \%$ of endometrial cancers (33), as well as in ascites cells isolated from patients with ovarian cancer $(34,35)$. Thus, MISRII

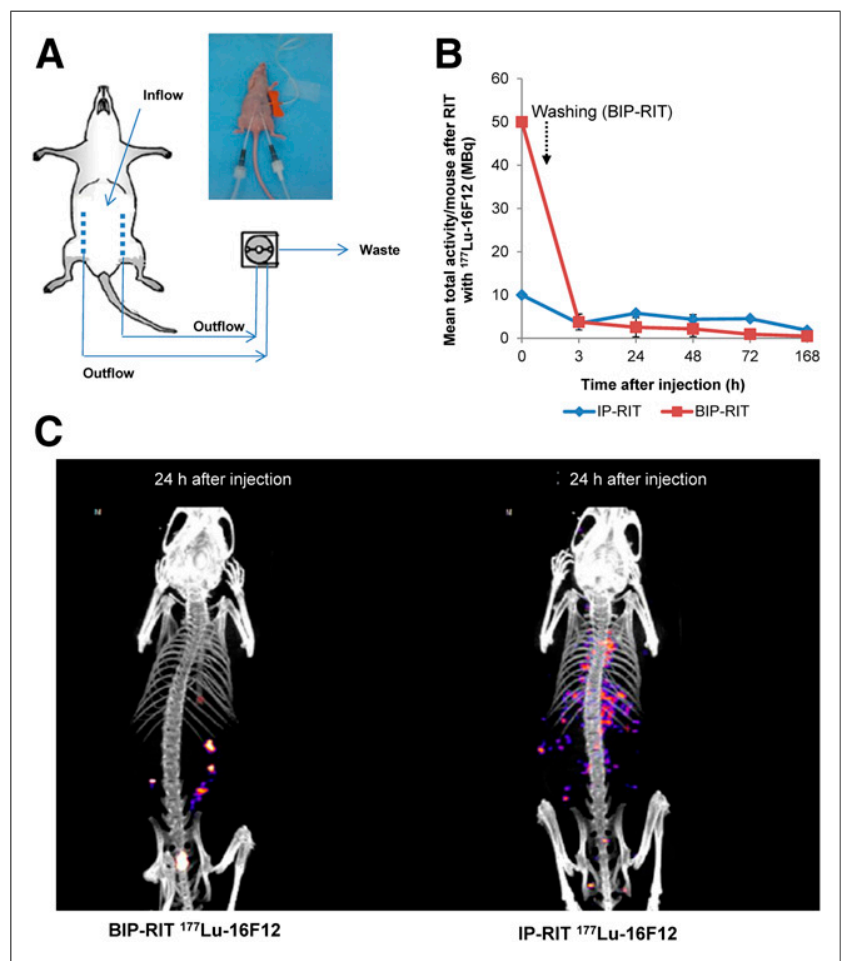

FIGURE 1. (A) Schematic representation of BIP-RIT approach, showing mean activity per whole mouse body at different time points after BIP-RIT (50 MBq) and IP-RIT (10 MBq) with ${ }^{177} \mathrm{Lu}-16 \mathrm{~F} 12$ ( $n=7$ mice/ group). ( $B$ and $C$ ) Merged whole-body SPECT/CT images of mice bearing AN3CA endometrial carcinoma cell tumor xenografts at $24 \mathrm{~h}$ after BIP-RIT (B) or IP-RIT (C). is highly expressed in many different gynecologic cancers, including tumors that lack effective systemic therapies.

In this preclinical study, we compared the therapeutic efficacy and hematologic toxicity of the $16 \mathrm{~F} 12 \mathrm{mAb}$ radiolabeled with $\beta$-particle $\left({ }^{177} \mathrm{Lu}\right)$ or $\alpha$-particle $\left({ }^{213} \mathrm{Bi}\right)$ emitters administered by conventional intraperitoneal radioimmunotherapy (IP-RIT) and by BIP-RIT. We also assessed ${ }^{89} \mathrm{Zr}-16 \mathrm{~F} 12$ for PET imaging.

\section{MATERIALS AND METHODS}

\section{Cell Line and Antibodies}

The AN3CA human endometrial carcinoma cell line was from the American Type Culture Collection. AN3CA cells were cultured in minimal essential medium with $10 \%$ fetal calf serum, $1 \%$ penicillin, $0.1 \%$ streptomycin, $1 \%$ sodium pyruvate, and $1 \%$ nonessential amino acids. MISRII expression in AN3CA cells was confirmed by flow cytometry analysis when the cells were received and again before each xenograft was implanted. The anti-MISRII 16F12 mAb was isolated from mouse hybridoma ascites, as previously described (36).

\section{Animals}

Female athymic nude-Foxn $1^{\text {nu }}$ mice (6-8 wk old) (Envigo RMS Laboratories) were kept in the animal facility for at least $1 \mathrm{wk}$ before use. They were housed at $22^{\circ} \mathrm{C}$ and $55 \%$ humidity, with a light-dark cycle of $12 \mathrm{~h}$ and ad libitum food and water. Body weight was monitored weekly, and the mice were examined throughout the study. They were intraperitoneally or subcutaneously xenografted with $4.5 \times 10^{6}$ AN3CA cells in RPMI medium with Matrigel (ratio, 1:1) in a volume of $200 \mu \mathrm{L}$. All animal experiments were performed in compliance with the French government guidelines and the INSERM standards for experimental animal studies (agreement B34-172-27). The study was approved by the ethics committees of the Institut de Recherche en Cancérologie de Montpellier (IRCM/INSERM) and the Languedoc Roussillon region (CEEA-LR-36) for animal experiments (reference number 1056).

\section{Conjugation of 16F12 mAb with DOTA, DTPA, or Deferoxamine Mesylate}

16F12-DOTA. Before radiolabeling with ${ }^{177} \mathrm{Lu}, 16 \mathrm{~F} 12$ was conjugated with $p$-SCN-Bn-DOTA (Macrocyclics). Briefly, $p$-SCN-BnDOTA was dissolved in conjugation buffer $\left(0.05 \mathrm{M} \mathrm{NaHCO}_{3}-\mathrm{Na}_{2} \mathrm{CO}_{3}\right.$, $0.15 \mathrm{M} \mathrm{NaCl}, 5 \mathrm{mM}$ ethylenediaminetetraacetic acid, $\mathrm{pH}$ 8.8), which had been diluted (1/10) before use. Next, 16F12 was added at a 15fold molar excess and incubated with stirring at $25^{\circ} \mathrm{C}$ for $19 \mathrm{~h}$. To remove free chelator, the mixture was washed 3 times with conjugation buffer using Amicon Ultra-15 centrifugal filter units (MerckMillipore) and then 3 times with $5 \mathrm{mM}$ ammonium acetate buffer $(\mathrm{pH}$ 7.0). The average number of DOTA molecules per mAb was assessed as previously described (37) and was between 5 and 7. All steps were performed in metal-free conditions.

16F12-DTPA. Before radiolabeling with ${ }^{213} \mathrm{Bi}, 16 \mathrm{~F} 12$ was conjugated with 2-( $p$-SCN-benzyl)-cyclohexyl acid A-diethylenetriaminepentaacetic (SCN-CHX-A" -DTPA; Macrocyclics). A solution of 0.35 $\mathrm{mg}$ of SCN-CHX-A" -DTPA dissolved in $1 \mathrm{~mL}$ of conjugation buffer (0.05 M NaHCO $3-\mathrm{Na}_{2} \mathrm{CO}_{3}, 0.15 \mathrm{M} \mathrm{NaCl}, \mathrm{pH}$ 8.5-8.9, containing $0.01 \mathrm{M}$ ethylenediaminetetraacetic acid, $\mathrm{pH} 4.5)$ was diluted (1/10) and mixed with $5 \mathrm{mg}$ of $16 \mathrm{~F} 12$ at a 15 -fold molar excess. The mixture was stirred at $25^{\circ} \mathrm{C}$ overnight. To remove unconjugated SCN-CHXA"-DTPA, the mixture was washed using Amicon Ultra-15 centrifugal filter units 3 times with conjugation buffer and then 3 times with $1 \mathrm{~mL}$ of $0.15 \mathrm{M} \mathrm{NaCl} / 0.05 \mathrm{M}$ sodium acetate $(\mathrm{pH}$ 7.2). The number of chelates per $\mathrm{mAb}$ was determined using the $\mathrm{Pb}$ (II)-Arsenazo III method (37) and was generally between 5 and 7. All steps were performed in metal-free conditions. 


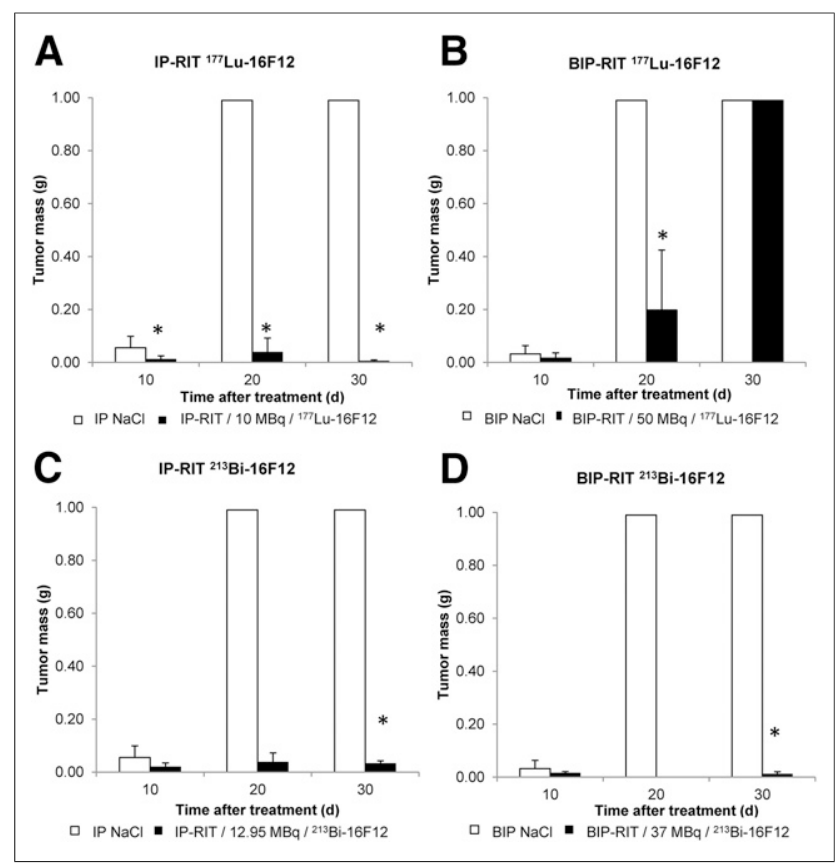

FIGURE 2. Therapeutic efficacy of ${ }^{177} \mathrm{Lu}-16 \mathrm{~F} 12$ ( $\mathrm{A}$ and $\mathrm{B}$ ) and ${ }^{213} \mathrm{Bi}-$ 16F12 (C and D) after IP-RIT (A and C) and BIP-RIT (B and D). Tumor mass (mean $\pm S D$ ) was calculated at days 10,20 , and 30 after treatment. ${ }^{*} P<0.05$ between therapeutic group and $\mathrm{NaCl}$ controls, between ${ }^{213} \mathrm{Bi}-$ $16 \mathrm{~F} 12$ and ${ }^{177} \mathrm{Lu}-16 \mathrm{~F} 12$, or between IP-RIT and BIP-RIT ( $n=7$ mice per group).

16F12-Deferoxamine Mesylate. The protocol described by Vosjan et al. was followed with slight modifications (38). Between 2 and $10 \mathrm{mg}$ of $16 \mathrm{~F} 12 \mathrm{mAb}(13.2-66 \mathrm{nmol})$ dissolved in $1 \mathrm{~mL}$ of buffer $(0.1 \mathrm{M}$ sodium carbonate) at $\mathrm{pH} 9.0$ was incubated with $20 \mu \mathrm{L}(2-10 \mathrm{mM})$ of $p$-isothiocyanatobenzyl-deferoxamine B (Df-Bz-NCS; Macrocyclics) dissolved in DMSO and incubated for $30 \mathrm{~min}$ at $37^{\circ} \mathrm{C}$ using a thermomixer at $550 \mathrm{rpm}$. The reaction mixture was purified on a PD-10 size-exclusion column (GE Healthcare) equilibrated on (and eluted with) gentisic acid $\left(5 \mathrm{mg} \cdot \mathrm{mL}^{-1}\right)$ in $0.25 \mathrm{M}$ sodium acetate $(\mathrm{pH}$ 5.4-5.6).

\section{Radiolabeling of Conjugated 16F12}

Production of ${ }^{177} \mathrm{Lu}$-DOTA-16F12 $\left({ }^{177} \mathrm{Lu}-16 \mathrm{F12}\right)$. For radiolabeling, $3.7 \mathrm{mg}$ of DOTA-16F12 was incubated with $740 \mathrm{MBq}$ of ${ }^{177} \mathrm{LuCl}_{3}$ (Perkin Elmer) at $37^{\circ} \mathrm{C}$ in $0.25 \mathrm{M}$ sodium acetate (pH 5.5) for $45 \mathrm{~min}$. The reaction was quenched with $100 \mu \mathrm{L}$ of $1 \mathrm{mM}$ DTPA. Radiolabeled mAbs were separated from free ${ }^{177} \mathrm{Lu}$ through a PD-10 column equilibrated with a $10 \mathrm{mg} / \mathrm{mL}$ solution of phosphate-buffered salinehuman serum albumin. The specific activity of the ${ }^{177} \mathrm{Lu}$-DOTA$16 \mathrm{~F} 12$ was between 150 and $200 \mathrm{MBq} / \mathrm{mg}$.

Production of ${ }^{213} \mathrm{Bi}$-DTPA-16F12 $\left({ }^{213} \mathrm{Bi}-16 \mathrm{~F} 12\right) .{ }^{213} \mathrm{Bi}$ was eluted from the ${ }^{225} \mathrm{Ac}$ generator provided by the Institute for Transuranium Elements using a mixture of $0.3 \mathrm{~mL}$ of $0.2 \mathrm{M} \mathrm{HCl}$ and $0.3 \mathrm{~mL}$ of $0.2 \mathrm{M} \mathrm{NaI}$. The eluate was collected directly into $0.12 \mathrm{~mL}$ of $4 \mathrm{M}$ sodium acetate and $0.05 \mathrm{~mL}$ of $20 \%$ ascorbic acid. The mixture $(\mathrm{pH}$ 5.3-5.5) was incubated with DTPA-16F12 (37 MBq/mg) at room temperature for $5 \mathrm{~min}$. The reaction was quenched with $10 \mu \mathrm{L}$ of a $1.5 \mathrm{mg} / \mathrm{mL}$ solution of DTPA.

Production of ${ }^{89} \mathrm{Zr}$-Deferoxamine Mesylate-16F12 ( ${ }^{89} \mathrm{Zr}$-16F12). The radiolabeling of Df-Bz-NCS-16F12 was performed as follows: $50-61 \mathrm{MBq}$ of ${ }^{89} \mathrm{Zr}$-oxalate, $31-33 \mu \mathrm{L}$ of $1 \mathrm{M}$ 4-(2-hydroxyethyl)-1-piperazineethanesulfonic acid, and 26-28 $\mu \mathrm{L}$ of $2 \mathrm{M} \mathrm{NaOH}$ were combined with $200-500 \mu \mathrm{g}$ of $\mathrm{mAb}$, and the reaction mixture was incubated for $1.5 \mathrm{~h}$ at room temperature. Reactions were then purified using a NAP5 column equilibrated on $0.25 \mathrm{M}$ sodium acetate, and fractions were collected. Fractions with purity greater than 99\% (silica-gel instant thin-layer liquid chromatography; Varian, $20 \mathrm{mM}$ citrate, $\mathrm{pH}$ 5.5) were combined and used for administration to animals $(100-120 \mathrm{MBq} / \mathrm{mg})$. The immunoreactive fraction of the purified product using the assay of Lindmo et al. in ANC3A cells was shown to be 1 (39).

\section{Radiochemical Purity and Immunoreactivity}

Immediately after radiolabeling, ${ }^{177} \mathrm{Lu}-16 \mathrm{~F} 12$ and ${ }^{213} \mathrm{Bi}-16 \mathrm{~F} 12 \mathrm{mAbs}$ were purified through PD-10 columns equilibrated with phosphatebuffered saline-human serum albumin, $10 \mathrm{mg} / \mathrm{mL}$. The radiochemical purity was determined using silica-gel instant thin-layer liquid chromatography (Varian) with $0.05 \mathrm{M}$ sodium citrate, $\mathrm{pH} 5.5$, as the mobile phase. The conjugated $\mathrm{mAb}$ immunoreactivity was checked using a Gallios Flow Cytometer (Beckman Coulter).

\section{IP-RIT and BIP-RIT}

At day 13 after xenograft implantation, when tumor size was about $80-100 \mathrm{~mm}^{3}$, the mice were divided into 6 groups $(n=7)$. Two groups were treated by IP-RIT with $500 \mu \mathrm{L}$ of either ${ }^{177} \mathrm{Lu}-16 \mathrm{~F} 12$ (200 MBq/mg, $10 \mathrm{MBq}$ ) or ${ }^{213} \mathrm{Bi}-16 \mathrm{~F} 12$ (37 MBq/mg, $\left.12.95 \mathrm{MBq}\right)$. Two groups were treated by BIP-RIT, with the peritoneal cavity being washed with $20 \mathrm{~mL}$ of saline solution $30 \mathrm{~min}$ after intraperitoneal injection of high activities $\left(500 \mu \mathrm{L}\right.$ of either ${ }^{177} \mathrm{Lu}-16 \mathrm{~F} 12 \mathrm{mAb}$ [200 MBq/mg, $50 \mathrm{MBq}]$ or ${ }^{213} \mathrm{Bi}-16 \mathrm{~F} 12 \mathrm{mAb}$ [37 MBq/mg, 37 $\mathrm{MBq}$ ) (Fig. 1A). Previous experiments showed that a single injection of nonradiolabeled $16 \mathrm{~F} 12$ at the concentration used for IP-RIT or BIPRIT has no therapeutic efficacy. Control groups included mice that received $\mathrm{NaCl}$ according to the IP-RIT and BIP-RIT methods.

Mouse weight was recorded throughout the study, and no clinical signs of pain or distress were seen. The mice were killed at 10,20, or $30 \mathrm{~d}$ after radioimmunotherapy to measure the tumor mass (i.e., sum of the weight of all tumor nodules).

\section{Biodistribution Analysis After IP-RIT or BIP-RIT}

For the biodistribution studies, radiolabeled antibody doses were supplemented with unlabeled $16 \mathrm{~F} 12$ to administer a quantity of antibodies similar to that during treatment. On the 13th postxenograft day, 4 mice per group received an intraperitoneal injection of $500 \mu \mathrm{L}$ of ${ }^{177} \mathrm{Lu}-16 \mathrm{~F} 12$ or ${ }^{213} \mathrm{Bi}-16 \mathrm{~F} 12$. For IP-RIT, $2 \mathrm{MBq}$ of ${ }^{177} \mathrm{Lu}-$ $16 \mathrm{~F} 12$ (adjusted to $40 \mathrm{MBq} / \mathrm{mg}$ with cold antibody) or $5.9 \mathrm{MBq}$ of ${ }^{213} \mathrm{Bi}-16 \mathrm{~F} 12$ (adjusted to $16.8 \mathrm{MBq} / \mathrm{mg}$ with cold antibody) was used. For BIP-RIT, $10 \mathrm{MBq}$ of ${ }^{177} \mathrm{Lu}-16 \mathrm{~F} 12$ (adjusted to $40 \mathrm{MBq} / \mathrm{mg}$ with cold antibody) or $10.2 \mathrm{MBq}$ of ${ }^{213} \mathrm{Bi}-16 \mathrm{~F} 12$ (adjusted to $10.2 \mathrm{MBq} / \mathrm{mg}$ with cold antibody) was used, followed by a peritoneal cavity wash.

The mice were killed at 3,24, 48, 72, or $168 \mathrm{~h}$ after injection of ${ }^{177} \mathrm{Lu}-16 \mathrm{~F} 12$ and at 1,2 , or $3 \mathrm{~h}$ after injection of ${ }^{213} \mathrm{Bi}-16 \mathrm{~F} 12$. Blood and healthy organs were collected and weighed, and radioactivity was measured using a $\gamma$-well counter (Hewlett Packard). Because the tumors were small, tumor mass was determined by measuring tumor volume using ImageJ and assuming a tumor density of $1.05 \mathrm{~g} \cdot \mathrm{cm}^{-3}$. The total tumor mass per mouse was calculated as the sum of the mass of all tumor nodules.

For IP-RIT, the percentage of injected activity per gram of tissue (\%IA/g) was calculated. For BIP-RIT, because of the peritoneal cavity wash, the percentage of residual activity per gram of tissue (\%RA/g) was calculated. These calculations required measurement of the total activity in the whole body at the time of dissection and were corrected for radioactive decay.

\section{Dosimetric Studies}

Biodistribution data were used to evaluate the radioactivity uptake per tissue mass $(\mathrm{Bq} / \mathrm{g})$ as a function of time. Time-activity curves for 


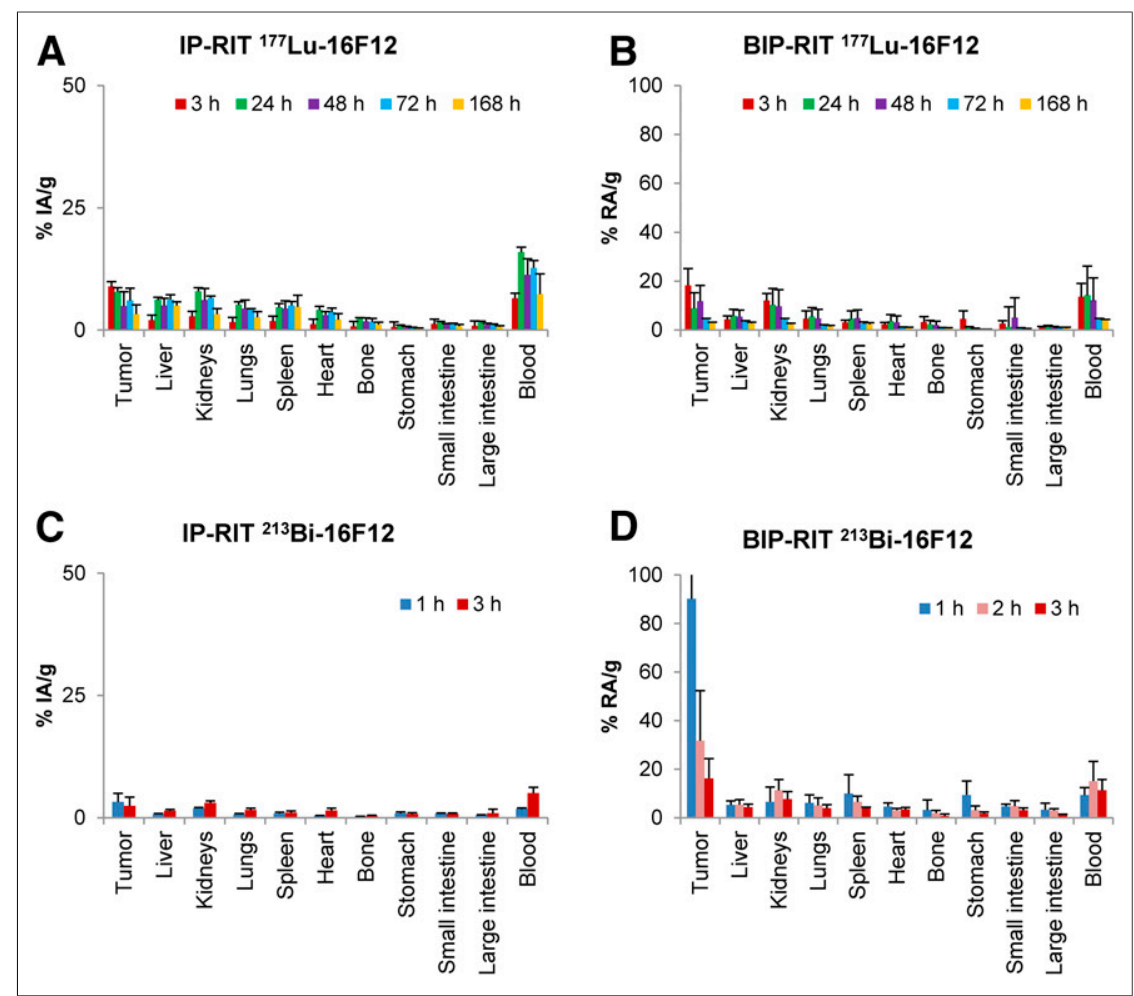

FIGURE 3. Tissue distribution of ${ }^{177} \mathrm{Lu}-16 \mathrm{~F} 12$ ( $\mathrm{A}$ and $\left.\mathrm{B}\right)$ and ${ }^{213} \mathrm{Bi}-16 \mathrm{~F} 12$ (C and D). Data are mean $( \pm \mathrm{SD}) \% \mathrm{IA} / \mathrm{g}$ after IP-RIT (A and C) or \%RA/g after BIP-RIT (B and D) ( $n=4$ mice/group).

each organ and for tumors were fitted by a monoexponential decay function or the sum of 2 exponential functions using PRISM 7 software (GraphPad Software, Inc.). The Akaike information criterion
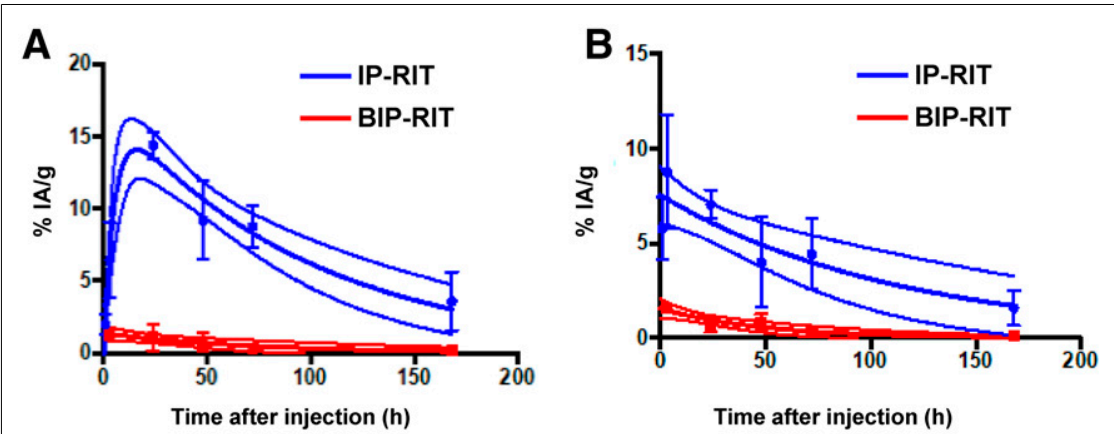

C
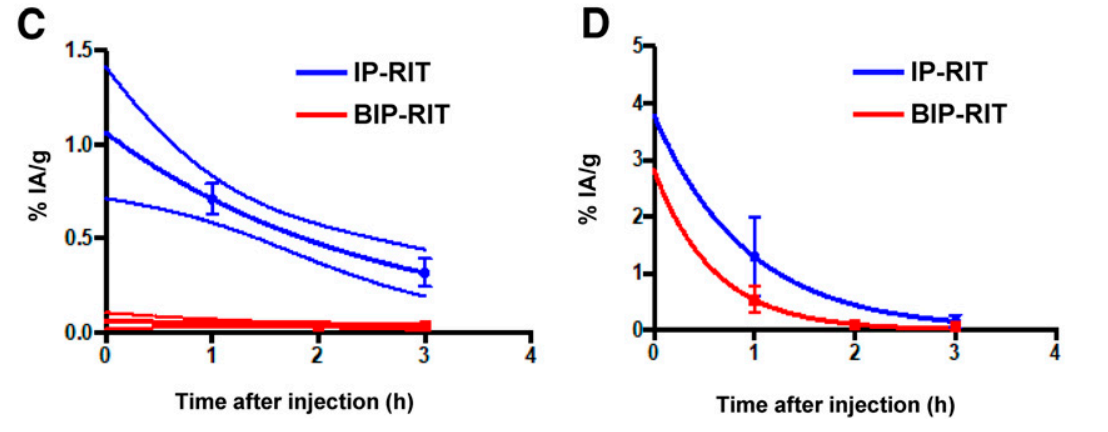

FIGURE 4. Time-activity curves (not corrected for decay) for blood (A) and AN3CA endometrial carcinoma cell tumor xenografts (B) measured with ${ }^{177} \mathrm{Lu}-16 \mathrm{~F} 12$ and for blood (C) and tumor (D) measured with ${ }^{213} \mathrm{Bi}-16 \mathrm{~F} 12$. Fitting of distribution (with $95 \%$ confidence intervals) using mono- or biexponential components is shown on A-C but, for sake of clarify, not on $\mathrm{D}$. was used to select the best-fitting function (40). In general, the sum of 2 exponential functions was used for IP-RIT with ${ }^{177} \mathrm{Lu}$ (except for tumors and muscle, for which the monoexponential decay was preferred), whereas for BIP-RIT with ${ }^{177} \mathrm{Lu}$ and ${ }^{213} \mathrm{Bi}$ and for IP-RIT with ${ }^{213} \mathrm{Bi}$, a monoexponential-decay fitting curve was chosen (with the exception of muscle for BIP-RIT with ${ }^{213} \mathrm{Bi}$ ). The time-integrated activity for each organ and for tumors was derived by calculating the area under each fitted time-activity curve. The absorbed dose was then calculated using the MIRD formalism (41). The time-activity curve for bone marrow was based on the blood data, considering a red-marrow-to-blood activity ratio of 0.4 , because $16 \mathrm{~F} 12$ is a full $\mathrm{IgG}$ that is not known to bind specifically to bone marrow (42).

For ${ }^{213} \mathrm{Bi}$ experiments, absorbed doses were calculated assuming a local energy deposition within all organs and tumors: time-integrated activities, weighed by the tissue mass, were multiplied by the energy of the emitted $\alpha$-particles (8.32 MeV per decay, considering the contribution of ${ }^{213} \mathrm{Bi}$ and ${ }^{213} \mathrm{Po}$ with the appropriate branching ratio, according to the MIRD radionuclide data and decay schemes (43)). For ${ }^{177} \mathrm{Lu}$ experiments, cross-fire irradiation between organs could contribute significantly to the absorbed doses received by the different organs. Therefore, the $\mathrm{S}$ values calculated for ${ }^{177} \mathrm{Lu}$ in a previously described 22 g-mouse model (44) were used. Self-dose S values were scaled to the measured organ masses. For bone marrow, the calculation was performed only for femoral bone marrow. Finally, self-dose $\mathrm{S}$ values for tumors were calculated using the Monte Carlo code GATE (45). Tumors were modeled using a unit-density sphere with a $1.1-\mathrm{mm}$ radius.

\section{Hematologic Toxicity}

Hematologic toxicity was assessed in tumor-free athymic nude mice after IP-RIT or BIP-RIT with ${ }^{213} \mathrm{Bi}-16 \mathrm{~F} 12$ and ${ }^{177} \mathrm{Lu}-$ 16F12. After radioimmunotherapy, $12 \mu \mathrm{L}$ of blood were collected from the tail in vials coated with ethylenediaminetetraacetic acid, twice a week for $3 \mathrm{wk}$ and then every week. White blood cell number and hemoglobin levels were quantified using the scil Vet abc system (scil Animal Care Co.).

\section{SPECT and PET Imaging Using 16F12}

${ }^{177} \mathrm{Lu}$ emits short-range $\beta$-particles and also low-energy $\gamma$-particles that are suitable for $\gamma$-imaging. Therefore, whole-body SPECT/CT images were acquired at different time points $(24,48,72$, and $96 \mathrm{~h}$ after radioimmunotherapy), using a 4-head NanoSPECT imager (Bioscan Inc.). The system was equipped with a tungsten-based collimator with nine 1-mm-diameter pinholes. The energy window was centered at $210 \mathrm{keV}$ with $\pm 20 \%$ width. Acquisition times were defined to obtain 30,000 counts for each projection 


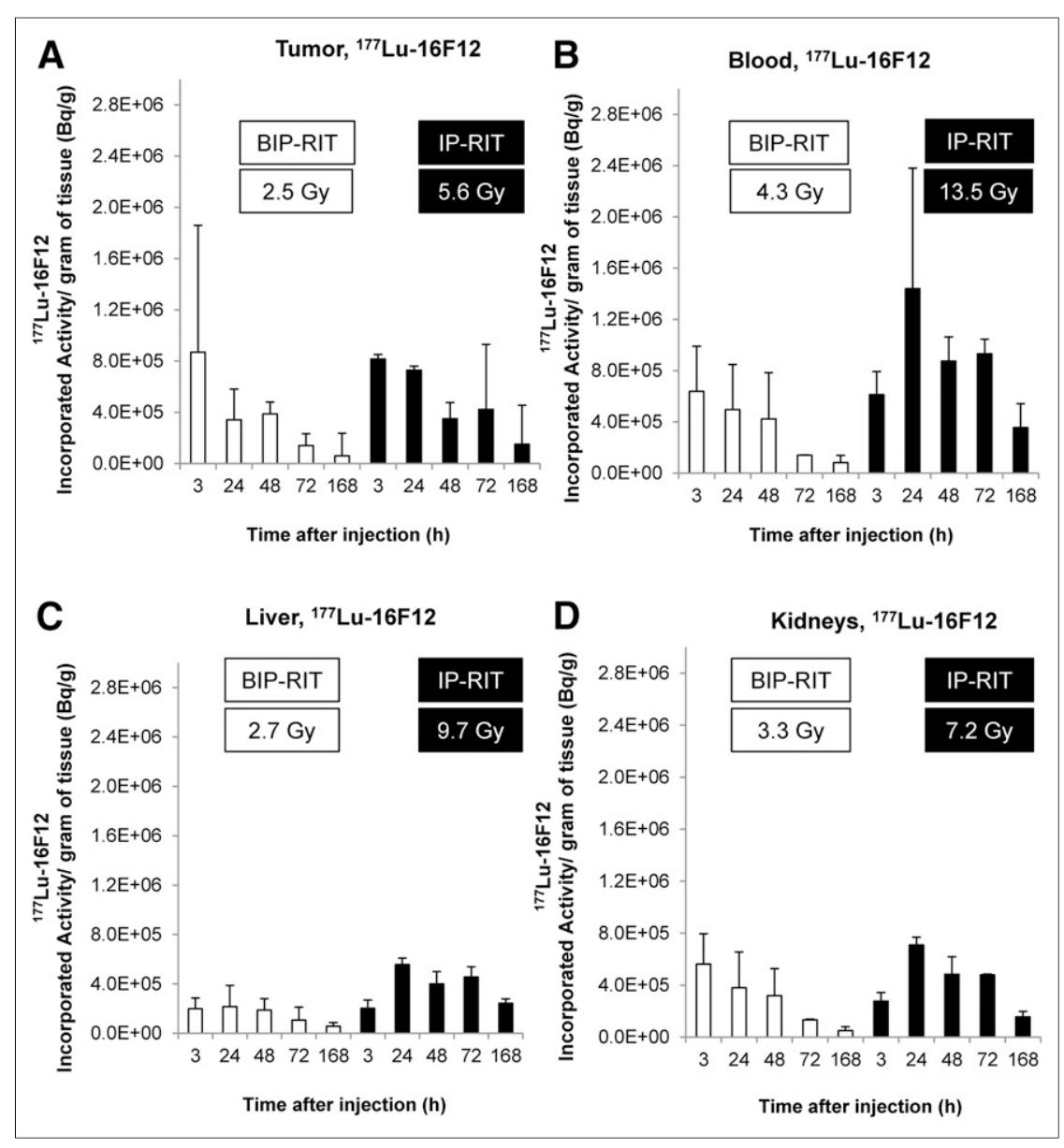

FIGURE 5. Incorporated therapeutic ${ }^{177}$ Lu-16F12 activity over time for tumors (A), blood (B), liver (C), and kidneys (D) after IP-RIT or BIP-RIT, with mean absorbed dose shown in key.

\section{RESULTS}

\section{Therapeutic Efficacy of BIP-RIT and IP-RIT}

First, the mean total activity was monitored at different times after BIP-RIT and IP-RIT in mice bearing intraperitoneal AN3CA cell xenografts. For BIP-RIT with ${ }^{177} \mathrm{Lu}-16 \mathrm{~F} 12$, the whole-body activity dropped from 50 to $3.8 \mathrm{MBq}(7.6 \%$ IA) immediately after washing of the peritoneal cavity (Fig. 1B). This value was quite close to the activity measured after IP-RIT (3.4 MBq). However, SPECT/CT images (Fig. 1C) showed that ${ }^{177} \mathrm{Lu}-$ $16 \mathrm{~F} 12$ was concentrated in tumors after BIP-RIT but diffused also into healthy tissues after IP-RIT.

In the $\mathrm{NaCl}$-treated groups, tumors reached a mass of $1 \mathrm{~g}$ in all mice by day 20 after treatment (Fig. 2). IP-RIT with $10 \mathrm{MBq}$ of ${ }^{177} \mathrm{Lu}-16 \mathrm{~F} 12$ strongly reduced tumor growth, as indicated by the significantly smaller tumor mass than in controls already at day $10(1.3 \pm$ $1 \times 10^{-3}$ g vs. $\left.6 \pm 4 \times 10^{-2} \mathrm{~g}\right)(P=0.017)$ (Fig. 2A).

In mice treated by BIP-RIT with 50 $\mathrm{MBq}$ of ${ }^{177} \mathrm{Lu}-16 \mathrm{~F} 12$, the tumor mass tended to be smaller than in controls at day 10. However, tumors progressively grew, and by day 30 all were larger than $1 \mathrm{~g}$ (Fig. 2B). In mice treated by IP-RIT with $12.95 \mathrm{MBq}$ of ${ }^{213} \mathrm{Bi}-16 \mathrm{~F} 12$, tumor growth was strongly reduced $(P=0.0102)$, with a mean tumor mass of $3.3 \pm 0.9 \times 10^{-2} \mathrm{~g}$ at day $30(>1 \mathrm{~g}$ in controls) (Fig. 2C). This

(generally $60-120 \mathrm{~s}$ were required) with 24 projections. The total scan time was 30-60 min. Small-animal CT whole-body images were acquired simultaneously (55 kV, $500 \mathrm{~ms}, 240$ projections). Reconstructed data from SPECT and CT images were visualized and coregistered using Invivoscope (Invicro, Inc.). Images and maximum-intensity projections were reconstructed using the dedicated Invivoscope software.

For PET imaging, a 7-wk-old female Foxn $1^{\text {nu }}$ mouse with a subcutaneous xenograft in the left flank received $8 \mathrm{MBq}$ of ${ }^{89} \mathrm{Zr}$-deferoxamine mesylate-16F12 intravenously, and PET imaging was performed under $1.5 \%$ isoflurane/oxygen $(1 \mathrm{~L} / \mathrm{min})$ anesthesia at $24,48,72$, and $96 \mathrm{~h}$ after injection. Images were acquired using an Inveon PET/CT scanner (Siemens Preclinical Solutions) and the following CT parameters: $80-\mathrm{kV}$ tube voltage, $500-\mu \mathrm{A}$ tube current, and $400-\mathrm{ms}$ exposure time. Then, PET images were acquired using a $350-$ to $650-\mathrm{keV}$ energy window and reconstructed to a $128 \times 128 \times 159$ matrix with a voxel size of 0.776 $\times 0.776 \times 0.796 \mathrm{~mm}$ using the 3 -dimensional ordered-subset expectation maximization reconstruction algorithm with $\mathrm{CT}$ attenuation and scatter correction (2 iterations of 3-dimensional ordered-subset expectation maximization, 18 maximum a priori iterations).

\section{Statistical Analysis}

Data were described using mean and SD or median and range. Treatment groups were compared using the nonparametric KruskalWallis test. All statistical tests were bilateral, and the statistical significance level was set at 5\%. Statistical analyses were done using STATA software (version 13.0; Stata Corp.). effect was even more marked $(P=0.0047)$ after BIP-RIT with 37 $\mathrm{MBq}$ of ${ }^{213} \mathrm{Bi}-16 \mathrm{~F} 12$ (mean tumor size, $1.2 \times 10^{-2} \pm 8 \times 10^{-3} \mathrm{~g}$ at day 30) (Fig. 2D). Overall, BIP-RIT with ${ }^{213} \mathrm{Bi}-16 \mathrm{~F} 12$ was more efficient in delaying tumor growth than IP-RIT with ${ }^{213} \mathrm{Bi}-16 \mathrm{~F} 12$ $(P=0.0339)$.

\section{F12 Concentration in Tumors after BIP-RIT}

For ${ }^{177} \mathrm{Lu}-16 \mathrm{~F} 12$, biodistribution analysis (corrected for decay) showed that the maximal tumor uptake and blood uptake were $8.9 \pm 3.1 \% \mathrm{IA} / \mathrm{g}$ (at $3 \mathrm{~h}$ ) and $15.9 \pm 1.04 \% \mathrm{IA} / \mathrm{g}$ (at $24 \mathrm{~h}$ ), respectively, after IP-RIT (Fig. 3A) and 18.3 $\pm 6.8 \%$ RA/g (at $3 \mathrm{~h}$ ) and $14.3 \pm 11.9$ $\%$ RA/g (at $24 \mathrm{~h}$ ), respectively, after BIP-RIT (Fig. 3B).

For ${ }^{213} \mathrm{Bi}-16 \mathrm{~F} 12$, biodistribution analysis (corrected for decay) showed that the maximal tumor uptake and blood uptake were $3.0 \pm$ $1.7 \% \mathrm{IA} / \mathrm{g}$ (at $1 \mathrm{~h}$ ) and $5.0 \pm 1.2 \% \mathrm{IA} / \mathrm{g}$ (at $3 \mathrm{~h}$ ), respectively, after IP-RIT (Fig. 3C) and 90.2 $\pm 19.3 \% \mathrm{RA} / \mathrm{g}$ (at $1 \mathrm{~h}$ ) and $15.05 \pm$ $8.1 \% \mathrm{RA} / \mathrm{g}$ (at $2 \mathrm{~h}$ ), respectively, after BIP-RIT (Fig. 3D).

\section{Incorporated Activity and Absorbed Doses}

For IP-RIT with ${ }^{177} \mathrm{Lu}-16 \mathrm{~F} 12$ (Fig. 4A), the activity concentration in blood (not corrected for decay) increased between 3 and $24 \mathrm{~h}$ after radioimmunotherapy and then progressively decreased. For BIP-RIT, the activity concentration in blood was much lower and decreased after $3 \mathrm{~h}$. Conversely, the tumor time-activity curves (Fig. 4B) were comparable for both radioimmunotherapy modalities with ${ }^{177} \mathrm{Lu}-16 \mathrm{~F} 12$ (i.e., the activity concentration 




FIGURE 6. Incorporated therapeutic ${ }^{213} \mathrm{Bi}-16 \mathrm{~F} 12$ activity over time for tumors (A), blood (B), liver (C), and kidneys (D) after IP-RIT or BIP-RIT, with mean absorbed dose shown in key. count was significantly reduced by $70 \%$ at day 10 after IP-RIT with ${ }^{177}$ Lu-16F12 but was back to normal within $30 \mathrm{~d}$. Conversely, white blood cell count was not negatively affected after BIP-RIT with ${ }^{177} \mathrm{Lu}-16 \mathrm{~F} 12$ or after BIPRIT or IP-RIT with ${ }^{213}$ Bi-16F12 (Fig. 7A). IPRIT with ${ }^{177} \mathrm{Lu}-16 \mathrm{~F} 12$ also transiently affected hemoglobin levels (decrease by $30 \%$ compared with control at day 10) (Fig. 7B) and led to significant weight loss. Conversely, weight continued to increase in the other 3 radioimmunotherapy groups (Fig. 7C).

\section{PET Imaging}

PET/CT images acquired at different time points after tail-vein injection of ${ }^{89} \mathrm{Zr}-16 \mathrm{~F} 12$ showed focal uptake at the site of the subcutaneous AN3CA cell tumor xenograft (Fig. 7B).

\section{DISCUSSION}

In this study, we assessed whether the new murine 16F12 mAb against human MISRII can be used as a theranostic tool in small-volume ovarian peritoneal carcinomatosis. For therapy, the $16 \mathrm{~F} 12 \mathrm{mAb}$ was radiolabeled with ${ }^{177} \mathrm{Lu}$ or with ${ }^{213} \mathrm{Bi}$, and two routes of administration were compared: conventional IP-RIT and the BIP-RIT developed by our team (25). The feasibility of BIP-RIT immediately after cytoreductive surgery, considering both radiation protection and technical constraints, has already been validated at the Montpellier Cancer Institute.

decreased after $3 \mathrm{~h}$ ), but the activity concentration was much higher for IP-RIT than for BIP-RIT. For IP-RIT and BIP-RIT with ${ }^{213} \mathrm{Bi}-16 \mathrm{~F} 12$, time-activity curves for blood (Fig. 4C) and for tumors (Fig. 4D) could be fitted with a monoexponential function. The blood activity concentration was much lower for BIP-RIT than for IP-RIT, whereas the activity concentrations within the tumors were similar for BIP-RIT and IP-RIT.

At therapeutic activities, absorbed dose calculations for ${ }^{177} \mathrm{Lu}-$ $16 \mathrm{~F} 12$ or ${ }^{213} \mathrm{Bi}-16 \mathrm{~F} 12$ after IP-RIT or BIP-RIT in tumors, blood, liver, and kidneys (Figs. 5 and 6; Tables 1 and 2) showed that they were always higher in healthy tissues after IP-RIT than after BIPRIT, irrespective of the radioimmunoconjugate used. In tumors, the absorbed dose of ${ }^{177} \mathrm{Lu}-16 \mathrm{~F} 12$ was higher after IP-RIT than after BIP-RIT, whereas that of ${ }^{213} \mathrm{Bi}-16 \mathrm{~F} 12$ was higher after BIP-RIT. The mean absorbed dose (Tables 1 and 2 ) in tumors was then $5.6 \pm 2.1$ Gy after IP-RIT with $10 \mathrm{MBq}$ of ${ }^{177} \mathrm{Lu}-16 \mathrm{~F} 12$, and $2.5 \pm 1$ Gy after BIP-RIT with $50 \mathrm{MBq}$ of ${ }^{177} \mathrm{Lu}-16 \mathrm{~F} 12$. Conversely, it was higher after BIP-RIT with $37 \mathrm{MBq}$ of ${ }^{213} \mathrm{Bi}-16 \mathrm{~F} 12$ than after IP-RIT with $12.95 \mathrm{MBq}$ of $\left.{ }^{213} \mathrm{Bi}-16 \mathrm{~F} 12\right)(3 \pm 2.98 \mathrm{~Gy}$ vs. $2.2 \pm 2.9 \mathrm{~Gy})$. Moreover, the absorbed doses in healthy organs were higher after IP-RIT than after BIP-RIT with ${ }^{177} \mathrm{Lu}-16 \mathrm{~F} 12$ and also, to a lesser extent, with ${ }^{213} \mathrm{Bi}-16 \mathrm{~F} 12$ (Tables 1 and 2).

\section{Hematologic Toxicity and Weight Loss}

Hematologic toxicity was assessed by quantifying white blood cell count and hemoglobin level. Compared with controls, white blood cell
As shown by SPECT/CT imaging and biodistribution/dosimetry studies, the main advantage of BIP-RIT over IP-RIT is the higher tumor-to-blood uptake ratio. For example, using the mean absorbed dose values from Tables 1 and 2, the tumor-to-blood absorbed dose ratios for the ${ }^{213} \mathrm{Bi}-16 \mathrm{~F} 12 \mathrm{mAb}$ are 1.4 and 6 after IP-RIT and BIP-RIT, respectively. This finding confirms our previous results obtained with an anti-carcinoembryonic antigen $\mathrm{mAb}$ radiolabeled with ${ }^{125} \mathrm{I}$ (25). Moreover, we found that the tumor-to-blood absorbed dose ratio was higher with ${ }^{213} \mathrm{Bi}$ than with ${ }^{177} \mathrm{Lu}(0.4$ and 0.6 for IP-RIT and BIP-RIT, respectively, with $\left.{ }^{177} \mathrm{Lu}-16 \mathrm{~F} 12\right)$. This observation can be explained by the fact that the ${ }^{213} \mathrm{Bi}$ short physical half-life corresponds roughly to the incubation time of the radioactive solution in the peritoneal cavity (because of removal of unbound radioactivity, decays occur mainly in the peritoneal cavity before systemic diffusion of the antibody in other healthy organs).

IP-RIT was slightly more efficient with ${ }^{177} \mathrm{Lu}-16 \mathrm{~F} 12$ than with ${ }^{213} \mathrm{Bi}-16 \mathrm{~F} 12$ (mean tumor mass, $0.01 \pm 0.003 \mathrm{~g}$ and $0.03 \pm 0.01 \mathrm{~g}$, respectively, at day 30; $P=0.0339$ ). The mean tumor-absorbed doses calculated for ${ }^{177} \mathrm{Lu}$ and ${ }^{213} \mathrm{Bi}$ were 5.6 and $2.2 \mathrm{~Gy}$, respectively, in agreement with the observed therapeutic effect. At day 30, an approximate relative biological effectiveness of 2.5 (i.e., 5.6/2.2) could be calculated by assuming that tumor masses were quite biological effectiveness value is slightly lower than that reported in the literature (between 4 and 5) $(46,47)$. The difference could be similar (relative to the control tumor size limit of $1 \mathrm{~g}$ ). This relative 
TABLE 1

Absorbed Doses After ${ }^{177}$ Lu-16F12 IP-RIT or BIP-RIT

\begin{tabular}{|c|c|c|c|c|}
\hline \multirow[b]{2}{*}{ Site } & \multicolumn{2}{|c|}{ IP-RIT } & \multicolumn{2}{|c|}{ BIP-RIT } \\
\hline & $\begin{array}{c}\text { Absorbed dose } \\
(\text { Gy/MBq) }\end{array}$ & $\begin{array}{l}\text { Absorbed dose, } \\
\text { therapy (Gy) }\end{array}$ & $\begin{array}{c}\text { Absorbed dose } \\
(\mathrm{Gy} / \mathrm{MBq})^{\star}\end{array}$ & $\begin{array}{c}\text { Absorbed dose, } \\
\text { therapy (Gy) }\end{array}$ \\
\hline Blood & $1.347 \pm 0.305$ & $13.5 \pm 3.0$ & $0.086 \pm 0.042$ & $4.3 \pm 2.1$ \\
\hline Tumor & $0.560 \pm 0.190$ & $5.6 \pm 2.1$ & $0.050 \pm 0.016$ & $2.5 \pm 1.0$ \\
\hline Liver & $0.973 \pm 0.244$ & $9.7 \pm 2.4$ & $0.054 \pm 0.030$ & $2.7 \pm 1.5$ \\
\hline Kidneys & $0.717 \pm 0.171$ & $7.2 \pm 1.7$ & $0.066 \pm 0.027$ & $3.3 \pm 1.3$ \\
\hline Lungs & $0.461 \pm 0.158$ & $4.6 \pm 1.6$ & $0.031 \pm 0.021$ & $1.5 \pm 1.1$ \\
\hline Spleen & $0.899 \pm 0.359$ & $9.0 \pm 3.6$ & $0.045 \pm 0.031$ & $2.2 \pm 1.5$ \\
\hline Heart & $0.388 \pm 0.108$ & $3.9 \pm 1.1$ & $0.024 \pm 0.018$ & $1.2 \pm 0.9$ \\
\hline Bones & $0.183 \pm 0.063$ & $1.8 \pm 0.6$ & $0.014 \pm 0.008$ & $0.7 \pm 0.4$ \\
\hline Stomach & $0.170 \pm 0.021$ & $1.7 \pm 0.2$ & $0.011 \pm 0.004$ & $0.6 \pm 0.2$ \\
\hline Small intestine & $0.178 \pm 0.045$ & $1.8 \pm 0.4$ & $0.008 \pm 0.003$ & $0.4 \pm 0.1$ \\
\hline Large intestine & $0.056 \pm 0.015$ & $0.6 \pm 0.1$ & $0.004 \pm 0.003$ & $0.2 \pm 0.1$ \\
\hline Carcass & $0.248 \pm 0.094$ & $2.5 \pm 0.9$ & $0.016 \pm 0.007$ & $0.8 \pm 0.3$ \\
\hline Bone marrow & $0.456 \pm 0.122$ & $4.6 \pm 1.2$ & $0.029 \pm 0.017$ & $1.5 \pm 0.8$ \\
\hline
\end{tabular}

${ }^{*}$ Corresponds to absorbed dose per unit of injected activity (MBq) during therapy.

Data are mean \pm SD.

explained by the uncertainties associated with relative biological effectiveness calculations in this case (in particular, only a single biologic endpoint considered). Also, strict relative biological effectiveness calculations refer to low-linear-energy-transfer $225-\mathrm{kV}$ $\mathrm{x}$-rays and not to $\beta$-particles.

Although ${ }^{177} \mathrm{Lu}-16 \mathrm{~F} 12$ was the most efficient after IP-RIT, hematologic toxicity was much lower with ${ }^{213} \mathrm{Bi}-16 \mathrm{~F} 12$, in agreement with the mean absorbed doses for ${ }^{177} \mathrm{Lu}-16 \mathrm{~F} 12$ and ${ }^{213} \mathrm{Bi}-16 \mathrm{~F} 12$ in blood (13.5 and 1.6 Gy, respectively) and bone marrow (4.6 and 0.65 Gy, respectively) after IP-RIT. BIP-RIT with ${ }^{177} \mathrm{Lu}-16 \mathrm{~F} 12 \mathrm{did}$ not have any therapeutic effect on tumor growth. Conversely, BIPRIT with ${ }^{213} \mathrm{Bi}-16 \mathrm{~F} 12$ efficiently reduced tumor growth (mean tumor mass, $0.012 \pm 0.008 \mathrm{~g}$ at day 30). This difference could be partly explained by the mean tumor-absorbed doses: 2.5 Gy for

TABLE 2

Absorbed Doses After ${ }^{213} \mathrm{Bi}-16 \mathrm{~F} 12$ IP-RIT or BIP-RIT

\begin{tabular}{|c|c|c|c|c|}
\hline \multirow[b]{2}{*}{ Site } & \multicolumn{2}{|c|}{ IP-RIT } & \multicolumn{2}{|c|}{ BIP-RIT } \\
\hline & $\begin{array}{l}\text { Absorbed dose } \\
(\mathrm{Gy} / \mathrm{MBq})^{*}\end{array}$ & $\begin{array}{l}\text { Absorbed dose, } \\
\text { therapy (Gy) }\end{array}$ & $\begin{array}{l}\text { Absorbed dose } \\
(\mathrm{Gy} / \mathrm{MBq})^{\star}\end{array}$ & $\begin{array}{c}\text { Absorbed dose, } \\
\text { therapy (Gy) }\end{array}$ \\
\hline Blood & $0.126 \pm 0.029$ & $1.63 \pm 0.37$ & $0.013 \pm 0.010$ & $0.49 \pm 0.37$ \\
\hline Tumor & $0.169 \pm 0.227$ & $2.18 \pm 2.95$ & $0.081 \pm 0.081$ & $3.00 \pm 2.98$ \\
\hline Liver & $0.042 \pm 0.011$ & $0.55 \pm 0.15$ & $0.004 \pm 0.003$ & $0.17 \pm 0.10$ \\
\hline Kidneys & $0.106 \pm 0.015$ & $1.37 \pm 0.20$ & $0.010 \pm 0.013$ & $0.38 \pm 0.47$ \\
\hline Lungs & $0.043 \pm 0.017$ & $0.55 \pm 0.22$ & $0.004 \pm 0.002$ & $0.16 \pm 0.09$ \\
\hline Spleen & $0.046 \pm 0.023$ & $0.60 \pm 0.30$ & $0.008 \pm 0.010$ & $0.30 \pm 0.36$ \\
\hline Heart & $0.038 \pm 0.019$ & $0.49 \pm 0.25$ & $0.003 \pm 0.002$ & $0.12 \pm 0.07$ \\
\hline Bones & $0.013 \pm 0.008$ & $0.17 \pm 0.10$ & $0.002 \pm 0.003$ & $0.08 \pm 0.10$ \\
\hline Stomach & $0.047 \pm 0.029$ & $0.61 \pm 0.37$ & $0.006 \pm 0.007$ & $0.24 \pm 0.24$ \\
\hline Small intestine & $0.045 \pm 0.009$ & $0.59 \pm 0.11$ & $0.004 \pm 0.003$ & $0.15 \pm 0.10$ \\
\hline Large intestine & $0.028 \pm 0.015$ & $0.37 \pm 0.19$ & $0.003 \pm 0.003$ & $0.10 \pm 0.11$ \\
\hline Carcass & $0.033 \pm 0.031$ & $0.42 \pm 0.40$ & $0.005 \pm 0.009$ & $0.20 \pm 0.33$ \\
\hline Bone marrow & $0.050 \pm 0.012$ & $0.65 \pm 0.15$ & $0.005 \pm 0.004$ & $0.20 \pm 0.15$ \\
\hline
\end{tabular}

${ }^{*}$ Corresponds to absorbed dose per unit of injected activity (MBq) during therapy.

Data are mean \pm SD. 


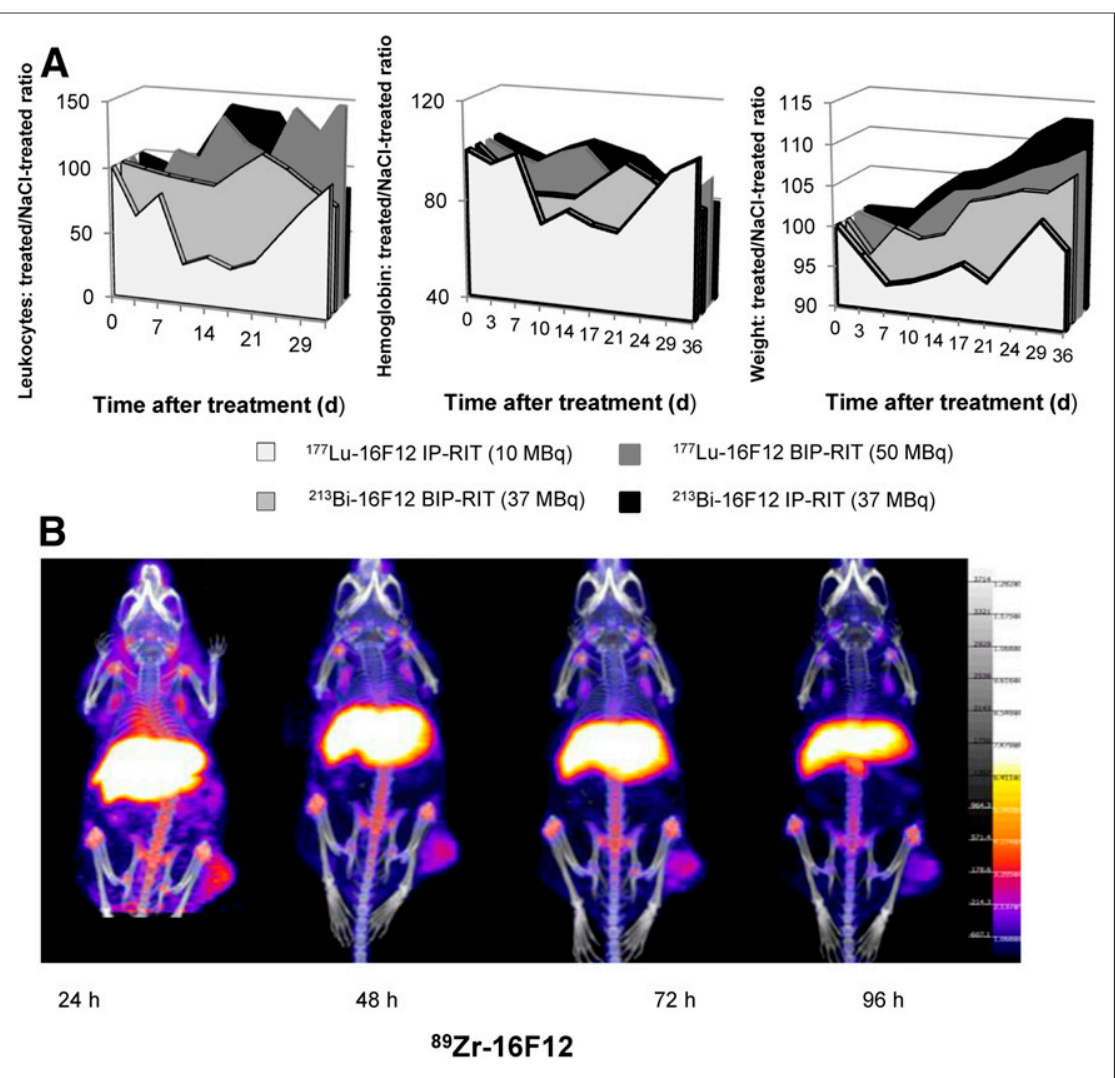

FIGURE 7. (A) Hematologic toxicity. White blood cell count, hemoglobin level, and weight were monitored in healthy mice at various times from days 0 to 36 after IP-RIT and BIP-RIT with ${ }^{177} \mathrm{Lu}$ $16 \mathrm{~F} 12$ or ${ }^{213} \mathrm{Bi}-16 \mathrm{~F} 12$ and expressed as ratio relative to treatment with $\mathrm{NaCl}$ control. (B) Wholebody PET/CT images of mice bearing subcutaneous AN3CA cell tumor xenografts in right flank at $24,48,72$, and $96 \mathrm{~h}$ after injection of ${ }^{89} \mathrm{Zr}-16 \mathrm{~F} 12 \mathrm{C}$.

${ }^{177} \mathrm{Lu}-16 \mathrm{~F} 12$ and $3 \mathrm{~Gy}$ for ${ }^{213} \mathrm{Bi}-16 \mathrm{~F} 12$. No hematologic toxicity was observed after BIP-RIT using $50 \mathrm{MBq}$ of ${ }^{177} \mathrm{Lu}-16 \mathrm{~F} 12$, possibly because of the lower transfer of radioactivity from the peritoneal cavity to blood ( $<10 \%$ in $30 \mathrm{~min}$ ) during BIP-RIT than during IP-RIT (activity in blood $30 \mathrm{~min}$ after injection/injected activity ratio, $\sim 3)$. This finding suggests that the ${ }^{177} \mathrm{Lu}-16 \mathrm{~F} 12$ injected activity could be increased to improve the therapeutic efficacy.

The advantage of using BIP-RIT with ${ }^{213} \mathrm{Bi}-\mathrm{mAbs}$ is clear, because compared with IP-RIT, this modality is associated with higher therapeutic efficacy and lower mean absorbed doses in healthy tissues. Typically, BIP-RIT allowed the blood-absorbed dose to be decreased from 4.3 to $0.5 \mathrm{~Gy}$, which could be a crucial advantage in chemotherapeutic drug combinations.

\section{CONCLUSION}

Our findings indicate that BIP-RIT with ${ }^{213} \mathrm{Bi}-16 \mathrm{~F} 12$ could be an attractive solution for adjuvant radioimmunotherapy at the surgery block immediately after cytoreduction to eliminate residual microscopic disease. Like hyperthermic intraperitoneal chemotherapy, this approach should be proposed to selected patients. Moreover, a first-in-human study using the anti-MISRII GM102 mAb in ovarian cancers is currently ongoing (NCT02978755). Compared with unlabeled antibodies, a radiolabeled anti-MISRII mAb could provide a diagnostic (when labeled with ${ }^{89} \mathrm{Zr}$ ) and therapeutic (when labeled with ${ }^{177} \mathrm{Lu}$ or ${ }^{213} \mathrm{Bi}$ ) advantage. Specifically, the radiolabeled antibodies can kill, through cross-fire irradiation and bystander effects, tumor cells that cannot be directly reached by the naked antibody. It is likely that the use of ${ }^{177} \mathrm{Lu}-16 \mathrm{~F} 12$ would be most advantageous when administered systemically to patients already treated by BIP-RIT.

\section{DISCLOSURE}

This research was funded by the French National Research Agency under the program "Investissements d'avenir" (grant agreement LabEx MAbImprove ANR-10-LABX-53), Electricité de France Comité de Radioprotection (RB 2017-12), Ligue Nationale Contre le Cancer (RF16011FF-RAB160), and GEFLUC Montpellier (53-R16018FF-RAK16002FFA). No other potential conflict of interest relevant to this article was reported.

\section{ACKNOWLEDGMENT}

We thank Dr. Erik Larsson (Lund University, Sweden) for providing the $\mathrm{S}$ values for ${ }^{177} \mathrm{Lu}$ absorbed dose calculations.

\section{REFERENCES}

1. Ferlay J, Soerjomataram I, Dikshit R, et al. Cancer incidence and mortality worldwide: sources, methods and major patterns in GLOBOCAN 2012. Int J Cancer. 2015;136:E359-E386.

2. Siegel RL, Miller KD, Jemal A. Cancer statistics, 2016. CA Cancer J Clin. 2016;66:7-30.

3. Jaaback K, Johnson N, Lawrie TA. Intraperitoneal chemotherapy for the initial management of primary epithelial ovarian cancer. Cochrane Database Syst Rev. 2016;CD005340

4. Sugarbaker PH, Cunliffe WJ, Belliveau J, et al. Rationale for integrating early postoperative intraperitoneal chemotherapy into the surgical treatment of gastrointestinal cancer. Semin Oncol. 1989;16:83-97.

5. Huo YR, Richards A, Liauw W, Morris DL. Hyperthermic intraperitoneal chemotherapy (HIPEC) and cytoreductive surgery (CRS) in ovarian cancer: a systematic review and meta-analysis. Eur J Surg Oncol. 2015;41:1578-1589.

6. Goodman MD, McPartland S, Detelich D, Saif MW. Chemotherapy for intraperitoneal use: a review of hyperthermic intraperitoneal chemotherapy and early post-operative intraperitoneal chemotherapy. J Gastrointest Oncol. 2016;7: 45-57.

7. Müller C, Zhernosekov K, Koster U, et al. A unique matched quadruplet of terbium radioisotopes for PET and SPECT and for $\alpha$ - and $\beta$-radionuclide therapy: an in vivo proof-of-concept study with a new receptor-targeted folate derivative. J Nucl Med. 2012;53:1951-1959.

8. Liu XY, Su X, Xie CJ, Li L, Yan JY, Sun ZY. Pharmacodynamic study of ${ }^{131} \mathrm{I}-$ labeled CA215 antibody on an animal model of estrogen-resistant OC-3-VGH ovarian cancer. Exp Ther Med. 2015;10:572-578.

9. Grünberg J, Lindenblatt D, Dorrer H, et al. Anti-L1CAM radioimmunotherapy is more effective with the radiolanthanide terbium-161 compared to lutetium177 in an ovarian cancer model. Eur J Nucl Med Mol Imaging. 2014;41:19071915.

10. Fischer E, Grunberg J, Cohrs S, et al. L1-CAM-targeted antibody therapy and ${ }^{177}$ Lu-radioimmunotherapy of disseminated ovarian cancer. Int J Cancer. 2012; 130:2715-2721.

11. Seidl C, Zockler C, Beck R, Quintanilla-Martinez L, Bruchertseifer F, Senekowitsch-Schmidtke R. ${ }^{177} \mathrm{Lu}$-immunotherapy of experimental peritoneal carcinomatosis shows comparable effectiveness to ${ }^{213} \mathrm{Bi}$-immunotherapy, but causes toxicity not observed with ${ }^{213} \mathrm{Bi}$. Eur J Nucl Med Mol Imaging. 2011;38:312-322.

12. Milenic DE, Wong KJ, Baidoo KE, et al. Targeting HER2: a report on the in vitro and in vivo pre-clinical data supporting trastuzumab as a radioimmunoconjugate for clinical trials. MAbs. 2010;2:550-564. 
13. Zacchetti A, Coliva A, Luison E, et al. ${ }^{177}$ Lu-labeled MOv18 as compared to ${ }^{131} \mathrm{I}-$ or ${ }^{90}$ Y-labeled MOv18 has the better therapeutic effect in eradication of alpha folate receptor-expressing tumor xenografts. Nucl Med Biol. 2009;36:759-770.

14. Syme A, McQuarrie S, Fallone BG. Beta dose-rate distributions in microscopic spherical tumors for intraperitoneal radioimmunotherapy. Int J Radiat Oncol Biol Phys. 2003;56:1495-1506.

15. Borchardt PE, Quadri SM, Freedman RS, Vriesendorp HM. Indium-111- and yttrium-90-labeled human monoclonal immunoglobulin $\mathrm{M}$ targeting of human ovarian cancer in mice. J Nucl Med. 1998;39:476-484.

16. Borchardt PE, Quadri SM, Freedman RS, Vriesendorp HM. Intraperitoneal radioimmunotherapy with human monoclonal IGM in nude mice with peritoneal carcinomatosis. Cancer Biother Radiopharm. 2000;15:53-64.

17. Janssen ML, Pels W, Massuger LF, et al. Intraperitoneal radioimmunotherapy in an ovarian carcinoma mouse model: effect of the radionuclide. Int $J$ Gynecol Cancer. 2003;13:607-613.

18. Elgqvist J, Andersson H, Back T, et al. Alpha-radioimmunotherapy of intraperitoneally growing OVCAR-3 tumors of variable dimensions: outcome related to measured tumor size and mean absorbed dose. J Nucl Med. 2006;47:1342-1350.

19. Gustafsson AM, Back T, Elgqvist J, et al. Comparison of therapeutic efficacy and biodistribution of ${ }^{213} \mathrm{Bi}$ - and ${ }^{211} \mathrm{At}-$ labeled monoclonal antibody MX35 in an ovarian cancer model. Nucl Med Biol. 2012;39:15-22.

20. Andersson H, Elgqvist J, Horvath G, et al. Astatine-211-labeled antibodies for treatment of disseminated ovarian cancer: an overview of results in an ovarian tumor model. Clin Cancer Res. 2003;9(suppl):3914S-3921S.

21. Palm S, Bäck TA, Lindegren S, Hultborn R, Jacobsson L, Albertsson P. Model of intraperitoneal targeted $\alpha$-particle therapy shows that posttherapy cold-antibody boost enhances microtumor radiation dose and treatable tumor sizes. J Nucl Med. 2018;59:646-651.

22. Gustafsson-Lutz A, Back T, Aneheim E, et al. Therapeutic efficacy of alpharadioimmunotherapy with different activity levels of the ${ }^{213} \mathrm{Bi}-l$ labeled monoclonal antibody MX35 in an ovarian cancer model. EJNMMI Res. 2017;7:38.

23. Bäck T, Chouin N, Lindegren S, et al. Cure of human ovarian carcinoma solid xenografts by fractionated alpha-radioimmunotherapy with ${ }^{211}$ At-MX35-F $\left(\mathrm{ab}^{\prime}\right)_{2}$ : influence of absorbed tumor dose and effect on long-term survival. J Nucl Med. 2017;58:598-604.

24. Boudousq V, Bobyk L, Busson M, et al. Comparison between internalizing antiHER2 mAbs and non-internalizing anti-CEA mAbs in alpha-radioimmunotherapy of small volume peritoneal carcinomatosis using ${ }^{212} \mathrm{~Pb}$. PLoS One. 2013;8: e69613.

25. Boudousq V, Ricaud S, Garambois V, et al. Brief intraperitoneal radioimmunotherapy of small peritoneal carcinomatosis using high activities of noninternalizing ${ }^{125}$ I-labeled monoclonal antibodies. J Nucl Med. 2010;51:1748-1755.

26. Santoro L, Boutaleb S, Garambois V, et al. Noninternalizing monoclonal antibodies are suitable candidates for ${ }^{125} \mathrm{I}$ radioimmunotherapy of small-volume peritoneal carcinomatosis. J Nucl Med. 2009;50:2033-2041.

27. Baranowska-Kortylewicz J. Intraperitoneal radioimmunotherapy: Auger electron emitters for solid tumors. Immunotherapy. 2011;3:491-494.

28. Verheijen RH, Massuger LF, Benigno BB, et al. Phase III trial of intraperitoneal therapy with yttrium-90-labeled HMFG1 murine monoclonal antibody in patients with epithelial ovarian cancer after a surgically defined complete remission. J Clin Oncol. 2006;24:571-578.

29. Teixeira J, Maheswaran S, Donahoe PK. Mullerian inhibiting substance: an instructive developmental hormone with diagnostic and possible therapeutic applications. Endocr Rev. 2001;22:657-674.
30. Imbeaud S, Faure E, Lamarre I, et al. Insensitivity to anti-Müllerian hormone due to a mutation in the human anti-Müllerian hormone receptor. Nat Genet. 1995; 11:382-388.

31. Jamin SP, Arango NA, Mishina Y, Hanks MC, Behringer RR. Genetic studies of the AMH/MIS signaling pathway for Müllerian duct regression. Mol Cell Endocrinol. 2003;211:15-19.

32. Rey R, Sabourin JC, Venara M, et al. Anti-Müllerian hormone is a specific marker of Sertoli- and granulosa-cell origin in gonadal tumors. Hum Pathol. 2000;31:1202-1208.

33. Bakkum-Gamez JN, Aletti G, Lewis KA, et al. Müllerian inhibiting substance type II receptor (MISIIR): a novel, tissue-specific target expressed by gynecologic cancers. Gynecol Oncol. 2008;108:141-148.

34. Song JY, Chen KY, Kim SY, et al. The expression of Müllerian inhibiting substance/anti-Müllerian hormone type II receptor protein and mRNA in benign, borderline and malignant ovarian neoplasia. Int J Oncol. 2009;34:1583-1591.

35. Pépin D, Sosulski A, Zhang L, et al. AAV9 delivering a modified human Müllerian inhibiting substance as a gene therapy in patient-derived xenografts of ovarian cancer. Proc Natl Acad Sci USA. 2015;112:E4418-E4427.

36. Salhi I, Cambon-Roques S, Lamarre I, et al. The anti-Müllerian hormone type II receptor: insights into the binding domains recognized by a monoclonal antibody and the natural ligand. Biochem J. 2004;379:785-793.

37. Dadachova E, Chappell LL, Brechbiel MW. Spectrophotometric method for determination of bifunctional macrocyclic ligands in macrocyclic ligand-protein conjugates. Nucl Med Biol. 1999;26:977-982.

38. Vosjan MJ, Perk LR, Visser GW, et al. Conjugation and radiolabeling of monoclonal antibodies with zirconium-89 for PET imaging using the bifunctional chelate p-isothiocyanatobenzyl-desferrioxamine. Nat Protoc. 2010;5:739-743.

39. Lindmo T, Boven E, Cuttitta F, Fedorko J, Bunn PA Jr. Determination of the immunoreactive fraction of radiolabeled monoclonal antibodies by linear extrapolation to binding at infinite antigen excess. J Immunol Methods. 1984;72:77-89.

40. Kletting P, Kull T, Reske SN, Glatting G. Comparing time activity curves using the Akaike information criterion. Phys Med Biol. 2009;54:N501-N507.

41. Loevinger R, Budinger T, Watson E. MIRD Primer for Absorbed Dose Calculations. Reston, VA: Society of Nuclear Medicine and Molecular Imaging; 1991.

42. Behr TM, Sgouros G, Stabin MG, et al. Studies on the red marrow dosimetry in radioimmunotherapy: an experimental investigation of factors influencing the radiation-induced myelotoxicity in therapy with beta-, Auger/conversion electron-, or alpha-emitters. Clin Cancer Res. 1999;5(suppl):3031s-3043s.

43. Eckerman KF, Akira E. MIRD: Radionuclide Data and Decay Schemes. Reston, VA: Society of Nuclear Medicine and Molecular Imaging; 2008.

44. Larsson E, Ljungberg M, Strand SE, Jonsson BA. Monte Carlo calculations of absorbed doses in tumours using a modified MOBY mouse phantom for preclinical dosimetry studies. Acta Oncol. 2011;50:973-980.

45. Sarrut D, Bardies M, Boussion N, et al. A review of the use and potential of the GATE Monte Carlo simulation code for radiation therapy and dosimetry applications. Med Phys. 2014;41:064301.

46. Dahle J, Abbas N, Bruland OS, Larsen RH. Toxicity and relative biological effectiveness of alpha emitting radioimmunoconjugates. Curr Radiopharm. 2011;4:321-328.

47. Graf F, Fahrer J, Maus S, et al. DNA double strand breaks as predictor of efficacy of the alpha-particle emitter Ac-225 and the electron emitter Lu-177 for somatostatin receptor targeted radiotherapy. PLoS One. 2014;9:e88239. 